\title{
KARAKTERISTIK MUTU BAKSO BELUT (Monopterus albus) DENGAN VARIASI SUBSTITUSI TEMPE
}

\section{CHARACTERISTICS OF QUALITY EEL (Monopterus albus) MEATBALLS WITH TEMPE SUBSTITUTION VARIATIONS}

\author{
Lina Widawati, Novian Firnando, Meirita Sari, Darius \\ Program Studi Teknologi Hasil Pertanian, Fakultas Pertanian, \\ Universitas Dehasen Bengkulu \\ Email : lina84id@gmail.com
}

\begin{abstract}
ABSTRAK
Bakso adalah jenis makanan olahan yang terbuat dari daging segar yang dicincang, bahan pengisi (filler), bahan pengikat, dan bumbu rempah. Selain daging sapi, bakso juga dapat dibuat dari daging belut karena daging belut mempunyai protein yang cukup tinggi. Tempe dapat dijadikan sebagai substitusi daging belut karena harga tempe lebih terjangkau dan kandungan proteinnya juga cukup tinggi. Tujuan penelitian ini adalah menganalisis pengaruh komposisi daging belut dan tempe terhadap kandungan protein dan organoleptik bakso belut. Hasil analisis menunjukkan bahwa semakin banyak penggunaan komposisi tempe maka kandungan protein bakso meningkat yaitu 19,27\%. Hasil analisis organoleptik terhadap warna, rasa, aroma dan tekstur bakso dengan perlakuan komposisi daging belut dan tempe menunjukkan beda nyata. Semakin banyak penggunaan komposisi tempe penilaian terhadap warna, rasa, aroma dan tekstur semakin menurun. Hasil rerata oranoleptik warna antara 3,75 (suka) hingga 4,25 (suka), rerata organoleptik rasa antara 3,65 (suka) hingga 4,05 (suka), rerata organoleptik aroma antara 3,35 (agak suka) hingga 4,30 (suka) dan rerata organoleptik tekstur antara 3,65 (suka) hingga 4,20 (suka).
\end{abstract}

Kata Kunci : bakso; daging belut; tempe

\begin{abstract}
Meatballs are a type of processed food made from chopped fresh meat, fillers, binders and spices. Besides beef, meatballs can also be made from eel meat because eel meat has a high enough protein. Tempe can be used as a substitute for eel meat because the price of tempe is more affordable and the protein content is also quite high. The purpose of this study was to analyze the effect of the composition of eel and tempe on the protein and organoleptic content of eel meatballs. The results of the analysis showed that the more use of tempe composition, the meatball protein content increased by 19.27\%. The results of organoleptic analysis of the color, taste, aroma and texture of meatballs with the treatment of eel and tempe composition showed significant differences. The more the use of tempe composition the assessment of color, taste, flavour and texture is decrease. The results of the average color oranoleptic are between 3,75 (likes) to 4,25 (likes), the average organoleptic taste is between 3,65 (likes) to 4,05 (likes), the average organoleptic flavour is between 3,35 (rather likes) to 4,30 (likes) and organoleptic texture averages between 3,65 (likes) to 4,20 (likes).
\end{abstract}

Kata Kunci : meatballs; eel meat; tempe 


\section{PENDAHULUAN}

Bakso merupakan jenis makanan olahan yang terbuat dari daging segar yang dicincang, bahan pengisi (filler), bahan pengikat serta bumbu dan rempah. Bakso merupakan salah satu makanan sumber protein yang cukup digemari oleh masyarakat. Bakso dapat dibuat dari berbagai macam daging yaitu daging sapi, daging ayam, daging ikan, maupun daging kelinci. Perbedaan daging penyusun inilah yang akan mempengaruhi jenis bakso tersebut (Wibowo, 2009).

Selain daging sapi, bakso juga dapat dibuat dari daging belut karena daging belut mempunyai protein dan gizi tinggi. Belut tergolong ikan yang memiliki kandungan protein dan vitamin A yang sangat baik. Komposisi zat gizi belut (Monopterus albus) tidak kalah tinggi dibandingkan dengan sumber protein hewan lainnya. Dalam 100 gram daging belut terkandung 14 gram protein, 27 gram lemak, $20 \mathrm{mg}$ kalsium, 1.600 SI, $2 \mathrm{mg}$ vitamin A, $2 \mathrm{mg}$ vitamin C,dan 0,1 mg vitamin B (Ruslan, 2009).

Salah satu kendala penggunaan daging belut sebagai bahan baku pembuatan bakso adalah harga daging belut di pasaran yang relatif tinggi. Oleh karena itu perlu dicari alternatif pengganti daging belut yang juga memiliki kandungan gizi setara belut salah satunya adalah tempe. (Menurut Astuti, 2000), tempe adalah makanan hasil fermentasi yang dibuat dari kedelai yang diinokulasi dengan jamur Rhizopus oligosporus dalam fermentasi padat.

Tempe dapat dijadikan sebagai substitusi daging belut karena harga tempe lebih terjangkau dan kandungan asam amino tempe setara dengan asam amino sapi. Protein tempe cukup tinggi hampir setara dengan daging sapi namun rendah kolesterol, sehinga tempe berpotesi melawan radikal bebas dan dapat mencegah berbagai penyakit, menghambat proses penuaan serta mencegah penyakit degenerative (Nout and Kiers, 2005). Asam lemak tidak jenuh pada tempe mempunyai efek penurunan terhadap kandungan kolesterol serum, sehingga dapat menetralkan efek negatif sterol di dalam tubuh. Pada tempe terdapat dua kelompok vitamin, yaitu larut air (vitamin B kompleks) dan larut lemak (vitamin A, D, E, dan K) (Sari dkk, 2016). Penggunaan daging belut yang baik disertai perbandingan tempe, penambahan bahan pengisi maupun pengikat, penggunaan bahan tambahan makanan yang aman serta cara pengolahan yang benar akan dihasilkan produk bakso yang berkualitas baik. Bakso yang berkualitas baik dapat dilihat dari tekstur, warna dan rasa bakso. Teksturnya yang halus, kenyal dan empuk, permukaan irisannya rata, dan 
serat dagingnya tidak tampak merupakan tekstur yang disukai konsumen (Sari dan Widjanarko, 2015). Oleh karena itu perlu dilakukan penelitian mengenai pengaruh komposisi daging belut dan tempe dalam pembuatan bakso.

\section{METODE PENELITIAN}

\section{Bahan dan Alat}

Bahan yang digunakan dalam penelitian ini adalah daging belut, tempe, tepung, tapioka, garam, bawang putih, bawang merah, merica, es batu serta bahan-bahan untuk analisis protein dan organoleptik bakso belut. Sedangkan alat yang digunakan dalam penelitian ini adalah timbangan analitik, kompor gas, gelas ukur, plastik, blender, wajan, pisau, baskom serta alat-alat untuk analisis protein dan organoleptik bakso belut.

\section{Prosedur Penelitian}

1. Disiapkan daging belut dan tempe yang masih segar.

2. Daging belut dibersikan dari kotoran dan darah dengan air bersih.

3. Daging dipotong kecil-kecil.

4. Tempe di potong kecil-kecil dan dikukus selama 20 menit

5. Daging belut dan tempe ditimbang sesuai dengan perlakuan (500 gram :

0 gram, 400 gram : 100 gram, 300

gram : 200 gram, 200 gram : 300

gram dan 100 gram : 400 gram).
6. Belut dan tempe digiling beserta es batu $15 \%$ dan ditambahkan dengan bumbu bawang merah $10 \%$, bawang putih $10 \%$, garam $2,5 \%$, merica $10 \%$ dan diaduk hinggga rata.

7. Adonan bakso belut dibentuk bulatbulat dan direbus selama 15 menit, diangkat, ditiriskan dan didinginkan.

8. Bakso belut selanjutnya dianalisis kadar protein dan sifat organoleptik.

\section{Rancangan Percobaan dan Analisis}

Rancangan yang digunakan dalam penelitian ini yaitu rancangan acak lengkap (RAL). Data yang diperoleh dianalisis dengan menggunakan metode analisis variance (ANOVA), jika terdapat perbedaan antar sampel maka akan dilanjutkan dengan uji beda nyata menggunakan analisis Duncan's Multiple Range Test (DMRT) pada taraf signifikansi 5\%. Perlakuan komposisi daging belut : tempe dapat dilihat sebagai berikut:

$\mathrm{F} 1=$ Daging belut 500 gram : Tempe 0 gram

F2 = Daging belut 400 gram : Tempe 100 gram

F3 = Daging belut 300 gram : Tempe 200 gram

F4 = Daging belut 200 gram : Tempe 300 gram

F5 = Daging belut 100 gram : Tempe 400 gram

Analisis yang dilakukan dalam penelitian ini adalah : analisis kandungan protein bakso (Sudarmadji dkk, 1996) dan 
analisis uji sensoris untuk mengetahui tingkat kesukaan panelis terhadap warna, rasa, aroma, dan tekstur bakso

\section{HASIL DAN PEMBAHASAN}

\section{Protein Bakso Belut}

Protein merupakan salah satu zat gizi makro utama bagi tubuh terkait dengan fungsinya sebagai zat pembangun, pengatur, dan sumber energi. (Winarno, 2009). Hasil analisis kandungan protein bakso belut dengan perbandingan daging belut dan tempe dapat dilihat pada Tabel 1. Tabel 1 menjelaskan hasil analisis kandungan protein bakso belut dengan perbandingan daging belut dan tempe (500 gram : 0 gram, 400 gram : 100 gram, 300 gram : 200 gram, 200 gram : 200 gram dan 100 gram : 400 gram) menunjukan beda nyata pada setiap perlakuan pada taraf signifikansi $5 \%$. Hasil analisis kandungan protein bakso dengan perbandingan daging belut dan tempe 500 gram : 0 gram sebesar 12,54\%, perbandingan daging belut dan tempe 400 gram : 100 gram sebesar 15,11\%, perbandingan daging belut dan tempe 300 gram : 200 gram sebesar 16,30\%, perbandingan daging belut dan tempe 200 gram : 300 gram sebesar 18,42\% dan perbandingan daging belut dan tempe 100 gram : 400 gram sebesar 19,27\%.
Kandungan protein bakso belut semakin tinggi dengan semakin tingginya penambahan tempe pada pengolahan bakso belut. Kandungan protein pada bakso dapat dipengaruhi oleh bakan baku yang digunakan yaitu daging belut dan tempe. Dimana kandungan protein belut sebesar 14 gram (Budi Santoso, 2010) lebih kecil jika dibandingkan dengan kandungan protein tempe yaitu sebesar 20,8 gram (Departemen Kesehatan RI, 1991), sehingga semakin banyak konsentrasi tempe yang ditambahkan akan meningkatkan kadar protein yang dihasilkan (Suyatno, 2010).

Hasil analisis protein bakso belut dengan perbandingan daging belut dan tempe berkisar antara $12,54 \%$ hingga 19,27\% dimana perlakuan perbandingan daging belut dan tempe (100 gram : 400 gram) menunjukkan kandungan protein tertinggi yaitu 19,27\%. Penambahan tempe dalam pengolahan bakso belut memberikan pengaruh yang nyata terhadap perlakaun. Kandungan protein bakso dengan perbandingan daging belut dan tempe sudah memenuhi standar SNI bakso, dimana menurut SNI 01-38181995 yang menetapkan kadar protein bakso daging minimal 9,0\%. 
Tabel. 1 Hasil Analisis Rerata Kandungan Protein Bakso Belut

\begin{tabular}{cc}
\hline Perlakuan & Kandungan Protein (\%) \\
\hline Daging belut 100 gram : Tempe 400 gram & $19,27^{\mathrm{a}}$ \\
Daging belut 200 gram : Tempe 300 gram & $18,42^{\mathrm{b}}$ \\
Daging belut 300 gram : Tempe 200 gram & $16,30^{\mathrm{c}}$ \\
Daging belut 400 gamr : Tempe 100 gram & $15,11^{\mathrm{d}}$ \\
Daging belut 500 gram : Tempe 0 gram & $12,54^{\mathrm{e}}$ \\
\hline
\end{tabular}

Ket :Angka yang diikuti oleh kode huruf yang berbeda menunjukkan adanya perbedaan yang nyata pada taraf signifikansi $5 \%$.

\section{Organoleptik Warna Bakso Belut}

Hasil uji organoleptik warna bakso belut dengan perbandingan daging belut dan tempe dapat dilihat pada tabel 2 . Tabel 2 menjelaskan nilai rerata uji organoleptik warna bakso dengan perbandingan daging belut dan tempe (500 gram : 0 gram dan 400 gram : 100 gram) menunjukkan tidak beda nyata akan tetapi berbeda nyata terhadap perbandingan daging belut dan tempe (300 gram : 200 gram, 200 gram : 300 gram dan 100 gram : 400 gram) pada taraf signifikansi 5\%. Rerata uji organoleptik panelis pada bakso belut dengan perlakuan perbandingan daging belut dan tempe 500 gram : 0 gram rerata 4,25 (suka), 400 gram : 100 gram rerata 4,15 (suka), 300 gram : 200 gram rerata 3,80 (suka), 200 gram : 300 gram rerata 3,75 (suka) dan perlakuan 100 gr : 400 gr rerata 3,80 (suka). Hasil rerata uji orgnoleptik warna bakso dengan perbandingan daging belut dan tempe setiap perlakuan berada pada skala suka, perlakuan 500 gram : 0 gram menunjukkan penilai panelis tertinggi dengan rerata 4,25 (suka).

Warna bakso dengan perlakuan perbandingan daging belut dan tempe menunjukan penilaian panelis berada pada skala suka dimana warna bakso yang dihasilkan yaitu abu-abu muda. Warna pada bakso dipengaruhi oleh bahan yang digunakan. Salah satu bahan dasar dalam pembuatan bakso yang mempengaruhi aspek warna adalah daging. Daging yang digunaka dalam pengolahan bakso yaitu daging belut yang memiliki warna putih keabu-abuan. Menurut Sudrajat (2007) warna bakso sangat dipengaruhi oleh warna daging yang berhubungan dengan kandungan mioglobin pada daging. 
Tabel 2. Hasil Rerata Uji Organoleptik Warna Bakso

\begin{tabular}{cc}
\hline \multicolumn{1}{c}{ Perlakuan } & Warna Bakso \\
\hline Daging belut 500 gram : Tempe 0 gram & $4,25^{\mathrm{a}}$ \\
Daging belut 400 gram : Tempe 100 gram & $4,15^{\mathrm{a}}$ \\
Daging belut 300 gram : Tempe 200 gram & $3,80^{\mathrm{b}}$ \\
Daging belut 200 gram : Tempe 300 gram & $3,75^{\mathrm{b}}$ \\
Daging belut 100 gram : Tempe 400 gram & $3,80^{\mathrm{b}}$ \\
\hline
\end{tabular}

Keterangan : angka yang diikuti oleh kode huruf yang berbeda menunjukkan adanya perbedaan yang nyata pada taraf signifikansi $5 \%$. Ket Skala : $5=$ sangat suka; $4=$ suka; $3=$ agak suka; 2 = tidak suka; 1 = sangat tidak suka

Warna pada bakso juga dipengarui oleh bahan tambahan seperti tempe yang digunakan berwarna putih sehingga dapat membentuk perubahan warna pada bakso. Warna pada bakso bervariasi namun idealnya berwarna putih keabu-abuan. Menurut Wibowo (2006) kriteria bakso yang baik yaitu berwarna coklat muda cerah, sedikit agak kemerahan, coklat muda hingga coklat muda agak keputihan atau abu-abu, warna merata tanpa warna lain yang mengganggu. Walaupun warnanya berbeda secara fisik, secara keseluruhan panelis tetap menyukai warna bakso dari setiap perlakuan. Hal ini sesuai dengan hasil penelitian Andayani (1999) menyatakan bahwa sebagian besar konsumen menyukai bakso berwarna abuabu pucat atau abu-abu muda.

\section{Organoleptik Rasa Bakso Belut}

Hasil uji organoleptik rasa bakso belut dengan perbandingan daging belut dan tempe dapat dilihat pada tabel 3 . Tabel 3 menjelaskan nilai rerata uji organoleptik rasa bakso dengan perlakuan perbandingan daging belut dan tempe (500 gram : 0 gram) menunjukkan berbeda tidak nyata terhadap perlakuan (400 gram : 100 gram, 300 gram : 200 gram dan 200gr : 300 gr) akan tetapi berbeda nyata dengan perlakuan (100 gram : 400 gram) pada taraf sigifikansi $5 \%$. Rerata hasil uji organoleptik bakso dengan perlakuan perbandingan daging belut dan tempe 500 gram : 0 gram rerata 4,05 (suka), 400 gram : 100 gram rerata 3,90 (suka), 300 gram : 200 gram rerata 3,95 (suka), 200 gram : 300 gram rerata 3,70 (suka) dan perlakuan 100 gram : 400 gram rerata 3.65 (suka). 


\section{Tabel 3. Hasil Rerata Uji Organoleptik Rasa Bakso}

\begin{tabular}{cc}
\hline \multicolumn{1}{c}{ Perlakuan } & Rasa Bakso \\
\hline Daging belut 500 gram : Tempe 0 gram & $4,05^{\mathrm{a}}$ \\
Daging belut 400 gram : Tempe 100 gram & $3,90^{\mathrm{ab}}$ \\
Daging belut 300 gram : Tempe 200 gram & $3,95^{\mathrm{ab}}$ \\
Daging belut 200 gram : Tempe 300 gram & $3,70^{\mathrm{ab}}$ \\
Daging belut 100 gram : Tempe 400 gram & $3,65^{\mathrm{b}}$
\end{tabular}

Keterangan : angka yang diikuti oleh kode huruf yang berbeda menunjukkan adanya perbedaan yang nyata pada taraf signifikansi $5 \%$. Ket Skala : $5=$ sangat suka; $4=$ suka; $3=$ agak suka; 2 = tidak suka; 1 = sangat tidak suka

Hasil rerata setiap perlakuan dengan perbandingan daging belut dan tempe pada setiap perlakuan berada pada skala suka, bakso dengan penggunaan daging belut $100 \%$ lebih disukai oleh panelis ditandai dengan penilaian panelis terhadap perlakuan komposisi daging belut dan tempe (500 gram : 0 gram) dengan rerata tertinggi yaitu 4,05 (suka) jika dibandingkan dengan perlakuan penambahan tempe. Rasa pada bakso ditimbulkan dari penggunaan bahan baku dalam pengolahan yaitu daging belut dan tempe serta penambahan bumbu. Secara umum bakso memiliki rasa gurih yang khas.

Bakso dengan mutu yang baik adalah bakso dengan rasa daging yang dominan dan rasa bumbu cukup menonjol tetapi tidak berlebihan (Wibowo 2006). Rasa gurih pada bakso terutama dipengaruhi oleh bumbu-bumbu yang dipakai. Pada kelima sampel bakso hasil eksperimen menggunakan komposisi bumbu yang sama, sehingga mempunyai rasa gurih yang hampir sama. Rasa gurih pada bakso dipengaruhi juga kandungan lemak yang terdapat pada bahan pembuatnya yaitu daging belut dan tempe. Menurut Meilgaard (2000), kandungan lemak dalam bahan pangan dapat menambah nilai gizi, kalori dan juga memberikan cita rasa gurih dari bahan pangan.

\section{Organoleptik Aroma Bakso}

Hasil uji organoleptik aroma bakso dengan perbandingan daging belut dan tempe dapat dilihat pada tabel 4 . Tabel 4 menjelaskan nilai rerata uji organoleptik aroma bakso dengan perlakuan perbandingan daging belut dan tempe (500 gram : 0 gram) menunjukkan berbeda tidak nyata terhadap perlakuan (400 gram : 100 gram dan 300 gram : 200 gram) akan tetapi berbeda nyata terhadap 
perlakuan (200 gram : 300 gram dan 100 gram : 400 gram) pada taraf signifikansi $5 \%$. Rerata aroma bakso belut dengan perlakuan perbandingan daging belut dan tempe 500 gram : 0 gram rerata 4,30 (suka), 400 gram : 100 gram rerata 4,00 (suka), 300 gram : 200 gram rerata 4,15 (suka), 200 gram : 300 gram rerata 3,95 (suka) dan perlakuan 100 gram : 400 gram rerata 3,35 (agak suka). Hasil uji organoleptik bakso dengan perlakuan perbandingan daging belut dan tempe 500 gram : 0 gram menunjukkan penilaian tertinggi yaitu 4,30 berada pada skala suka, sedangkan perlakuan dengan perbandingan daging belut dan tempe 100 gram : 400 gram menunjukkan penilaian panelis terendah yaitu 3,35 berada pada skala agak suka. Penambahan tempe yang semakin tinggi mempengaruhi penilaian panelis terhadap bakso belut yang dihasilkan, dimana aroma bakso dengan semakin tinggi penambahan tempe menimbulkan aroma khas tempe.

Bakso belut dengan penambahan tempe yang semakin tinggi memiliki aroma daging yang kurang kuat. Hal ini disebabkan jumlah tempe lebih besar menutupi aroma dari bakso. Aroma yang ditimbulkan agak berbau tempe. Oleh karena itu, semakin tinggi jumlah tempe yang digunakan tingkat penilaian panelis semakin rendah menunjukkan kesukaan panelis terhadap aroma bakso semakin menurun. Andayani (1999) menyatakan bahwa panelis menyukai aroma bakso yang dihasilkan disebabkan oleh aroma khas daging sapi yang kuat. Panelis yang pada umumnya mengkonsumsi dan menyukai bakso dengan aroma daging rebus.

\section{Tabel 4 Hasil Rerata Uji Organoleptik Aroma Bakso}

\begin{tabular}{cc}
\hline \multicolumn{1}{c}{ Perlakuan } & Aroma Bakso \\
\hline Daging belut 500 gram : Tempe 0 gram & $4,30^{\mathrm{a}}$ \\
Daging belut 400 gram : Tempe 100 gram & $4,00^{\mathrm{ab}}$ \\
Daging belut 300 gram : Tempe 200 gram & $4,15^{\mathrm{ab}}$ \\
Daging belut 200 gram : Tempe 300 gram & $3,95^{\mathrm{b}}$ \\
Daging belut 100 gram : Tempe 400 gram & $3,35^{\mathrm{c}}$
\end{tabular}

Keterangan : angka yang diikuti oleh kode huruf yang berbeda menunjukkan adanya perbedaan yang nyata pada taraf signifikansi $5 \%$. Ket Skala : $5=$ sangat suka; $4=$ suka; $3=$ agak suka; 2 = tidak suka; 1 = sangat tidak suka 


\section{Organoleptik Tekstur Bakso Belut}

Hasil uji organoleptik tekstur bakso dengan perbandingan daging belut dan tempe dapat dilihat pada Tabel 5. Tabel menjelaskan nilai rerata uji organoleptik tekstur bakso dengan perlakuan perbandingan daging belut dan tempe (500 gram : 0 gram) menunjukkan berbeda tidak nyata terhadap perlakuan (400 gram : 100 gram dan 300 gram : 200 gram) akan tetapi berbeda nyata terhadap perlakuan (200 gram : 300 gram dan 100 gram : 400 gram) pada taraf signifikansi $5 \%$. Rerata uji organoleptik tekstur bakso dengan komposisi daging belut dan tempe 500 gram : 0 gram dengan rerata 4,20 (suka), 400 gram : 100 gram rerata 4,10 (suka), 300 gram : 200 gram rerata 4,05 (suka), 200 gram : 300 gram rerata 3,70 (suka) dan perlakuan 100 gram : 200 gram rerata 3,65 (suka). Perlakuan dengan komposisi daging belut dan tempe 500 gram : 0 gram menunjukkan penilain panelis terendah dengan 4,20 berada pada skala suka sedangkan perlakuan dengan komposisi daging belut dan tempe 200 gram : 300 gram dengan rerata 3,90 (suka) menunjukkan penilaian panelis terendah.

Tekstur bakso dipengarui oleh kualitas dan jenis bahan baku (daging) yang digunakan, jenis dan presentase tepung pati serta pada proses pembuatan. Kualitas daging akan menentukan mutunya, yaitu semakin segar daging yang dipakai maka semakin bagus mutu bakso yang dihasilkan (Wibowo 2006). Salah satu syarat mutu bakso yang baik bisa ditinjau dari teksturnya yaitu kenyal. Felicia, (2010) menyatakan sifat kekenyalan bakso juga dipengaruhi oleh bahan pengisi, karena bahan pengisi berupa tepung mengikat air, saat dipanaskan tepung juga mempunyai sifat kenyal sehingga bakso yang dihasilkan dapat lebih kenyal.

Tabel 5. Hasil Rerata Uji Organoleptik Tekstur Bakso

\begin{tabular}{cc}
\hline Perlakuan & Tekstur Bakso \\
\hline Daging belut 500 gram : Tempe 0 gram & $4,20^{\mathrm{a}}$ \\
Daging belut 400 gram : Tempe 100 gram & $4,10^{\mathrm{ab}}$ \\
Daging belut 300 gram : Tempe 200 gram & $4,05^{\mathrm{ab}}$ \\
Daging belut 200 gram : Tempe 300 gram & $3,70^{\mathrm{b}}$ \\
Daging belut 100 gram : Tempe 400 gram & $3,65^{\mathrm{b}}$
\end{tabular}

Keterangan : angka yang diikuti oleh kode huruf yang berbeda menunjukkan adanya perbedaan yang nyata pada taraf signifikansi $5 \%$. Ket Skala : $5=$ sangat suka; $4=$ suka; $3=$ agak suka; 2 = tidak suka; 1 = sangat tidak suka 


\section{KESIMPULAN}

Hasil analisis kandungan protein bakso belut dengan perbandinan daging belut dan tempe berkisar antara 12,54\% hingga $19,27 \%$. Semakin banyak penggunaan komposisi tempe maka kandungan protein bakso belut semakin meningkat.Semakin banyak penggunaan komposisi tempe penilaian terhadap warna, rasa, aroma dan tekstur semakin menurun. Hasil rerata oranoleptik warna antara 3,75 (suka) hingga 4,25 (suka), rerata organoleptik rasa antara 3,65 (suka) hingga 4,05 (suka), rerata organoleptik aroma antara 3,35 (agak suka) hingga 4,30 (suka) dan rerata organoleptik tekstur antara 3,65 (suka) hingga 4,20 (suka).

\section{DAFTAR PUSTAKA}

Andayani, R.Y. 1999. Standarisasi mutu bakso berdasarkan penilaian konsumen (studi kasus bakso di wilayah DKI Jakarta). Fakultas Teknologi Pertanian Institut Pertanian Bogor, Bogor. Skripsi.

Astuti, M., M Andreanyta, S.F. Dalais, M.L. Wahlqvist. 2000. Tempe, a Nutritious and Healthy Food from Indonesia. Asia Pacific Journal of Clinic and Nutrition. Vol. 9

Felicia. 2010. Penggunaan pati sagu termodifikasi dengan heat moisture treatment (HMT) untuk meningkatkan kualitas tekstur bakso daging sapi. Skripsi. Institut Pertanian Bogor. Bogor

Meilgaard. 2000. Sensory Evalution Teechniques. CRC. Boston.
Nout, M.J.R. and Kiers, J.L. 2005. Tempe fermentation, innovationand functionality: update into the third milenium. Journal of Applied Microbiolog. 98: 789-805

Ruslan, Roy. 2009. Buku Pintar Budidaya dan Bisnis Belut. Agromedia Pustaka. Jakarta

Sari, H.A dan Widjanarko, S.M. 2015 Karakteristik Kimia Bakso Sapi (Kajian Proporsi Tepung Tapioka: Tepung Porang dan Penambahan $\mathrm{NaCl}$ ). Jurnal Pangan dan Agroindustri Vol. 3 No 3 p.784792, Juli 2015

Sari, K, P., Jamaluddin, P dan Sukainah, A. 2016. Fortifikasi Tempe Berbahan Dasar Kedelai dan Biji Nangka. Jurnal Pendidikan Teknologi Pertanian, Vol. 2

Sudarmadji, S., Haryono B., dan Suhardi. 1997. Prosedur untuk Uji Analisis Makanan dan Pertanian. Liberty. Yogyakarta.

Soekarto, S.T. 1985. Penilaian Organoleptik. Bhatara Karya Aksara. Jakarta

Sudrajat, G. 2007. Sifat Fisik Dan Organoleptik Bakso Daging Sapi dan Daging Kerbau Dengan Penambahan Karagenan dan Khitosan. Skripsi. Fakultas Pertanian, Institut Pertanian Bogor. Bogor

Suyatno. 2010. DKBM-Indonesia. http://suyatno.blog.undip.ac.id/file s/2010/ 04/ DKBM-Indonesia.pdf. Diakses : 29 Maret 2019.

Wibowo S. 2006. Pembuatan Bakso Ikan dan Bakso Daging. Penebar Swadaya. Jakarta.

Wibowo, 2009, Bakso dan jenis olahan Universitas Sumatera Utara PT.Gramedia Pustaka Utama, Jakarta.

Winarno FG. 2009. Kimia Pangan dan Gizi. Jakarta (ID): M-Brio Press. 